\title{
Framework for Decentralising Municipal Solid Waste Management in Harare, Zimbabwe
}

Trust Nhubu ${ }^{1, *}$, Edison Muzenda ${ }^{1,2}$, Mohamed Belaid ${ }^{1}$, Charles Mbohwa ${ }^{3}$

${ }^{1}$ Department of Chemical Engineering Technology, University of Johannesburg, Johannesburg, 0027, South Africa

${ }^{2}$ Department of Chemical, Materials and Metallurgical Engineering, Botswana International University of Science and Technology, Palapye, 00267, Botswana

${ }^{3}$ Department of Quality and Operations Management, University of Johannesburg, Johannesburg, 0027, South Africa

\begin{tabular}{l} 
A R T I C L E I N F O \\
\hline Article history: \\
Received: 22 December, 2020 \\
Accepted: 12 April, 2021 \\
Online: 22 April, 2021 \\
\hline Keywords: \\
Anaerobic digestion \\
Backyard composting \\
Community based municipal solid \\
waste management \\
Composting \\
Municipal solid waste \\
Decentralisation \\
Incineration \\
Integrated municipal solid waste \\
management \\
Recycling \\
Harare \\
Zimbabwe
\end{tabular}

\section{Introduction}

This paper is a revised and extended version of a paper entitled, "Options for decentralised municipal solid waste management in Harare, Zimbabwe", that was presented at the 7th International Renewable and Sustainable Energy Conference (IRSEC' 19), Sofitel Agadir Royal Bay, Agadir, Morocco, November 27-30, 2019.

*Corresponding Author: Trust Nhubu, Cr Siemert \& Beit Streets, Doornfontein, Johannesburg, South Africa, 2094,+263777342295, nhubutrust@gmail.com

\begin{tabular}{l} 
A B S T R A C T \\
Municipal Solid Waste Management (MSWM) decentralisation brings about reductions in \\
the amount of municipal solid waste (MSW) earmarked for landfilling worse still under \\
situations where MSW is being sent to dumpsites. It also reduces the distances MSW \\
collection vehicles travel during MSW collection, maintenance and transport costs due to \\
the establishment of local level decentralised MSWM and treatment facilities. Subsequently \\
fuel use, greenhouse gas and other emissions together with MSWM associated \\
environmental and human health risks are reduced. The Zimbabwe National Integrated Solid \\
Waste Management Plan (ZNISWMP) provides for the need for decentralisation in MSWM. \\
This study therefore assessed the framework along which MSWM decentralisation can be \\
achieved in Harare. The study noted the presence of various opportunities for MSWM \\
decentralisation in Harare namely household backyard composting, community level and \\
industrial scale anaerobic digestion or composting of organic MSW fraction, anaerobic co- \\
digestion of organic MSW fraction and dewatered sewage sludge, MSW source separation \\
for material recovery, establishment of waste transfer stations, citizens drop off centers, buy \\
back centers and thermal treatment facilities associated with energy recovery. Though the \\
NISWMP plan provides for concrete actions for MSWM decentralisation, the study observed \\
that almost all of the proposed actions have not been implemented hence the need for urgent \\
review and subsequent operationalization and implementation of the review findings. \\
MSWM has also been hindered by the lack oflegislative and institutional reforms with ULAs \\
remaining reluctant to devolve and delegate some of the MSWM responsibilities and \\
functions to other players prompting the need for such reforms to be implemented as \\
provided in goal 10 of plan. The Presidential national cleanup day proclamation needs to \\
be complemented with other initiatives that will increase residents' interest in participation, \\
allow for different types of participation such as provision of resources and equipment and \\
above all the development of sustainable MSW disposal facilities unlike dumpsites. \\
\hline
\end{tabular}

In Zimbabwe, municipal solid waste management (MSWM) is a designated authority of urban local authorities (ULAs) including councils largely implemented under a conventional and centralised system [1-3]. Like most ULAs in Africa, the ULAs within and in the vicinity of the Harare metropolitan province in Zimbabwe are experiencing MSWM failures. These failures are largely due to increased municipal solid waste (MSW) generation emanating from increased urban population and improved lifestyles. The municipalities, town councils, local boards and rural district 
MSWM failures thus are a manifestation of mismatch between increased MSW generation and investment in MSWM and accompanying necessary infrastructural development. Other factors leading to MSWM failures are poor governance and inadequate capacity to fully adopt technology intensive MSWM and treatment methods being developed in the developed world.

The limited and or no external investment as well as the over reliance on rate payers characterizing the MSWM in the ULAs in and around Harare is largely unsustainable posing MSWM related human health and environmental hazards. Residents have developed general unwillingness to pay attitude and regard MSWM a sole responsibility of ULAs thus they resort to indiscriminate or irresponsible dumping of MSW in undesignated areas when over $50 \%$ of the MSW generated remain uncollected as reported by [4]. ULAs regard residents as MSWM rates or service payers who must only participate in MSWM through paying for MSWM services that would have been provided. The prevailing MSWM model thus lacks all the necessary partnership and cooperation ingredients amongst the stakeholders specifically between the residents served by MSWM systems and ULAs [2, 5]. The model does not provide adequate environment for residents as well as other stakeholders involvement in MSWM [6].

ULAs attributes the residents' inability and unwillingness to pay to the unsustainable, ineffective and inefficient MSWM systems currently prevailing within their jurisdictions. The residents on the other hand attribute their unwillingness and failure to pay for MSWM services to the poor MSWM services delivered, abuse of resources by the ULAs' executives and the general economic hardships emanating from the prevailing economic environment. Such contradictions shows the ineffectiveness, inefficiency and unsustainability of the conventional and centralised MSWM model inherited from the colonial era and being implemented in developing countries [7, 8]. Municipalities and or ULAs face financial constraints that hinder MSWM efficiency [9-11] leading to low or no collection of MSW generated [12-14]. The low or no MSW collection fuels illegal as well as indiscriminate open dumping, burying and burning of MSW in undesignated areas $[4,15,16]$. MSWM system failures, therefore, become inevitable and expected to worsen in Harare due to the residents' unwillingness and inability to pay as well as the absence of alternative financing sources. In addition MSWM system failures in developing countries has also been linked to the continued dependence on the linear MSW generation, collection, transportation and final disposal model or approach under the conventional and centralised system because of its rigidity that hinders the local level solutions acceptance and adoption of specific and unique local MSWM requirements [17]. Such MSWM approaches are not designed to bring solutions to MSWM associated complexity since one compartmentalized MSWM solution is likely to generate other MSWM problems [18]. Therefore, the linear (generation, collection, transportation and disposal), conventional and centralised model being implemented in developing countries and specifically in Harare is discredited for being a problem transfer (MSW transfer) from MSW sources to disposal sites especially land intensive dumpsites and landfills [19]. Zimbabwe thus realised and noted its lack of capacity to effectively provide MSWM services in its urban environments under the prevailing MSWM system or model and initiated the process of developing a national integrated solid waste management plan (NISWMP) in 2010 [20].

The Zimbabwe NISWMP amongst eight of the issues it sought to address noted in another study [21] speak on the limitations of the conventional and centralised MSWM system specifically the continued reliance on MSW generation, storage, collection and transportation and then final disposal by ULAs in Zimbabwe with major challenges being experienced under collection, transportation and disposal resulting from failures to meet the increased waste generation; lack of effort towards avoiding or preventing, reducing and controlling the increasing waste generation; and non-involvement, lack of participation and consultation of stakeholders especially the residents who are served by MSWM systems as well as the private sector since MSWM is largely a preserve of ULAs and their hired agents. In attempting to address the mentioned shortcomings the Zimbabwe NISWMP provides for decentralised MSWM options and the promotion of stakeholders' participation in MSWM within Zimbabwean urban environments. The Zimbabwe NISWMP's goal 10 of strategy $\mathrm{C}$ under action 5 (A5) provides for MSWM authority to be decentralised to the lowest appropriate level and enhancing ULAs' capacities to fulfil their obligations. Zimbabwe does not have a national waste management policy and Goal 10 provides for the need to develop one and review and assess the current legislative and institutional arrangements for the purpose of improving implementation [20]. This study, therefore, reviews MSWM models together with the associated available options for MSWM decentralisation in ULAs within and surrounding Harare City considering the MSWM decentralisation proposals in the Zimbabwe NISWMP as well as from other literature sources.

\section{Decentralisation in MSWM}

MSWM decentralisation encompasses relevant stakeholders' involvement and participation especially the residents and those who use and are served by the MSWM system. Stakeholder participation is integral in both community based municipal solid waste management (CBMSWM) and integrated municipal solid waste management (IMSWM) considering that MSWM sustainability is attained only when local authorities accept its corresponding management system. Such a MSWM system must be realistic and appropriate in providing solutions to the available and specific MSWM circumstances and challenges of an urban area (city, town, local board, growth point etc) and its surroundings. It must also be able to engage and capacitate all its stakeholders and users namely households, private businesses together with their employees, government departments (local, regional and national), non-governmental organisations including donors and international financing simultaneously recognizing and considering their socio-economic, political, cultural and environmental status.

\subsection{Community Based Municipal Solid Waste Management (CBMSWM)}

Communities are considered active role players under CBMSWM when it comes to the cleaning of their environments which has the potential of providing them with livelihoods in as far as earning an income from MSW [22, 23] and by taking advantage of the belief and understanding that people are likely to change their behaviours and attitudes towards something if they are part 
of problem identification and solution design. Strong relationships are therefore built amongst the various MSWM stakeholders namely ULAs, residents and private business. It is under such CBMSWM that communities and residents bear the responsibility of providing clean and sanitary environments in the vicinity of their households and residences by discarding MSW in designated receptacles. Communities and residents are also potential agents for materials recovery (recycling and reuse) from MSW, backyard compositing of organic MSW fraction, MSW separation at source including at households and or other MSW generation sources which will be collected by respective MSW fractions collectors. They can as well resultantly deliver their source separated MSW fractions to any of the following: citizens drop of centers (CDOPs) or citizens convenient centers (CCCs), buy back centers (BBCs), waste transfer stations (WTS), materials recovery facilities, specific MSW fraction treatment facilities (anaerobic digestion and or composting for organic MSW fractions, incinerators, pyrolysis and gasification plants and landfills). In addition, they can as well perform other administrative MSWM functions such as recording MSW collection services like the daily number of premises and households served, quantity of MSW collected etc. within their localities $[9,14,24]$.

CBMSWM provides communities and residents with the opportunity to be involved and participate in MSWM meetings, elect their local representatives and leaders responsible for the management of MSW collection and providing residents feedback and complaints to the ULAs. In addition to the role played by communities and residents in MSWM, CBMSWM recognizes the vital role of community-based organisations (CBOs) and that of local private businesses. Authors in [25] and [26] reported that CBMSWM has brought some improvements in MSWM in household or residential areas regardless of the other social challenges reported to have been encountered in some developing countries during its implementation $[3,27]$ as well as the negative perception regarding MSWM being considered a sole responsibility of ULAs [3, 28].

\subsection{Integrated Municipal Solid Waste Management (IMSWM)}

IMSWM model has received global acceptance as a system that could address the current MSWM challenges with full scale operationalisation and implementation having been achieved in the developed nations whereas developing nations are also making significant strides towards its operationalisation and implementation. IMSWM emerged from the need for MSWM shift from landfilling as the sole disposal method to a wider and holistic perspective that incorporated value extraction through materials and energy recovery from MSW that started in the 1990s. The need to shift from MSW landfilling as envisaged under the IMSWM model however is despite the continued reliance on dumpsites in some or majority of developing countries making the transition from dumpsites to landfilling inevitable, thus a transition that will not include landfilling which is to be avoided under the IMSWM for these developing countries will be too huge and difficult to implement. The IMSWM model is meant to bring about the necessary trade-offs regarding the effectiveness of the environmental sustainability, economic affordability and social acceptability dimensions of a MSWM system [29, 30]. The authors in [29] further pointed out that IMSWM focuses on integrating the numerous MSWM processes namely; MSW generation, storage, collection and transportation, treatment or processing methods, recovery of materials and energy, final disposal and entities (MSW producers and users, managers and policy formulators, governments, financiers and funders) that form a MSWM system to bring about continuous improvement together with the MSWM associated environmental impacts and costs reduction. The design of IMSWM systems is meant to achieve specific local level MSWM goals taking into consideration the prevailing MSW generation and characteristic together with the available and appropriate MSW prevention, reduction, reuse and recycle and final disposal methods, political, socio-economic, cultural, environmental and institutional systems factoring in stakeholders' perspectives and needs $[29,31,32]$ which guarantees the needed MSWM systems decentralisation and sustainability since ignoring these social aspects and other local level priorities have led to systems failures $[33,34]$.

Effectiveness in a MSWM system is attained when both ULAs and residents fully embrace it thus departing from the traditional system where experts design and outline MSWM solutions prior to the involvement of residents meant to be serviced by the MSWM system. This is largely so since MSWM system acceptance by residents is anchored on their involvement and participation during planning, design, development, implementation and operationalisation with the evolving value systems, consumer attitudes, perceptions and behaviours being equally important as the technical and economic aspects [33, 34].

The traditional meaning of waste which is subjective in that it attaches a negative value on MSW by regarding it an unwanted item or material to the disposer is regarded only true in the IMSWM system only when the MSW waste has been utilised to its full potential leaving no further processing potential to recover materials and energy $[18,32]$. IMSWM thus brings together the waste hierarchy elements factoring in the associated MSWM direct impacts from MSW generation, storage, collection and transportation, treatment and processing and final disposal together with indirect impacts from the use of recovered materials and energy [10]. Various players therefore, can take different roles along the different IMSWM system stages instead of having ULAs being the sole players responsible for the entire MSWM system functions. This brings about the much-needed decentralisation as well as specialisation. For instance, collection and transportation, treatment and processing may be delegated to other players whilst the final disposal be the duty of other players.

\section{Support Pillars for MSWM Decentralisation in the NIMSWMP}

The NISWMP provides several key strategies and action points under its goals 1 to 10 that support decentralisation of MSWM within ULAs in Zimbabwe. Such key actions include but not limited to the need for reduction in waste, source separation of MSW, reuse of biodegradable MSW for gardening and livestock feed at household level, establishment of viable markets for biodegradable MSW, production of manure from biodegradable MSW composting or vermi-composting, establishment of community and industrial recycling centers, development of recycling projects at institutions such as schools, tertiary education institutions and hotels, construction of $\mathrm{AD}$ facilities at established recycling centers and institutions like schools, universities, prisons 
as well as markets and hotels, establish combined Heat and Power (CHP) generation facilities from AD derived biogas, putting in place a kerbside collection system with citizens' drop off or citizens' convenient centers where households or institutions bring waste as provided in Table 1.

All these key actions provided in the NISWMP with regards to enhancing decentralisation speaks on the need for stakeholder participation in MSWM which is further affirmed under goal 8 which seeks to promote cleanliness in Zimbabwe by involving the public, industry and government in efforts towards reducing, reusing and recycling all solid waste materials to manage and mitigate the MSW associated public health and environmental impacts. In addition, Goal 7 of the NISWMP supports decentralisation as it seeks to educate and raise awareness amongst Zimbabwean citizens to better understand the importance of participating in source separation; materials and resources recovery and integrated and sustainable solid waste management thus the high literacy level in Zimbabwe is believed will enhance citizens participation easing the introduction and implementation of decentralised waste management systems. Interestingly the tenth goal of the plan seeks to review and assess current legislation and institutional arrangements to improve implementation of ISWM amongst its key actions under its strategy $\mathrm{C}$ is the need to decentralize MSWM authority to the lowest appropriate level as well as strengthening the capacities of ULAs to meet their obligations with regards to decentralizing MSWM authorities.

\section{Proposals for MSWM Decentralisation in Harare}

The ULAs that constitutes Harare metropolitan province include Harare the Capital City of Zimbabwe, Chitungwiza municipality and Epworth Local Board. Other two ULAs that borders Harare city namely Ruwa Local Board to the east and Norton Local Boards to the west are generally considered part of ULAs that constitutes what is loosely termed Harare. The waste generation figures in these ULAs are as given in Table 2. Currently each ULA is responsible for the management of the MSW generated within their jurisdictions. These ULAs are indiscriminately collecting less than $50 \%$ of the MSW generated and dump it at open non engineered or sanitary dumpsites serve for Norton which has an engineered sanitary landfill whose environmental soundness is under questioning. Several options for decentralised management and treatment of the MSW fractions generated within a specific jurisdiction as shown in Table 2 can be pursued. The options for treating these MSW fractions generated should be focused on AD of biodegradable MSW fraction, recycling of at least $20 \%$ and incineration of at most $80 \%$ of the non-biodegradable fractions. The focus on the mentioned MSW treatment is informed by study findings from [35] which identified the option incorporating $\mathrm{AD}$ of organic fraction of MSW, at least $20 \%$ and at most 80 percent recycling and incineration of the nonorganic MSW fraction generated in Harare respectively being the least environmentally impactful option. Composting of the biodegradable MSW fractions could also be considered after AD due to the better environmental performance and overall edge of $\mathrm{AD}$ over composting resulting from its renewable energy production capabilities and other associated benefits noted by [36].

\subsection{Biological Treatment}

The AD of the organic MSW fraction generated in Harare (136,612 tons), Chitungwiza (32, 822tons), Norton (6,21tons), Ruwa (5, 213tons) and Epworth (15,403tons) could be done at household, institutional, community or industrial scale. Households and institutions (schools, universities, hotels etc.) could source separate their biodegradable MSW they generate and feed it into purposely built small biogas digesters from which they can get biogas for their domestic cooking. Community level AD systems could therefore bring medium to large scale operation of up to 100,000 tons per annum where ULAs could partner with private sector, institutions and local residents. Further upgrading of biogas utilisation at institutional or community levels to install combined heat and power (CHP) generation units where the biogas produced from $\mathrm{AD}$ is burnt to generate renewable electricity and heat. The biodegradable MSW could also be composted at household and institutional level through backyard composting thereby reducing MSW amount transported for disposal at landfills in the face of heightened global concern against the landfilling of biodegradable MSW fractions. Other medium and large-scale composting facilities could also be established by the private sectors, ULAs and residents. The establishment of household and institutional $\mathrm{AD}$ and composting facilities as well as community or industrial scale $\mathrm{AD}$ and composting facilities within the neighborhood where the biodegradable MSW is generated brings about a reduction in MSW amount on a weight and volume basis to be transported to landfills. The number of trips and distance travelled by MSW collection vehicles are reduced subsequently reducing fuel consumption, MSW collection and transportation associated greenhouse gases (GHG) emissions, vehicles maintenance and overall costs. However, need for capacity building arises to avoid any unintended health and environmental impacts from the improper operation of household $\mathrm{AD}$ and backyard composting. Medium scale to large scale $\mathrm{AD}$ and composting facilities under decentralisation can be operated by the private operators with communities, institutions and ULAs facilitating source separation of organics to ensure the necessary $\mathrm{AD}$ and composting feedstock quality. ULAs will therefore collect and deposit their sorted organic waste to the composting and $\mathrm{AD}$ facilities at nominal agreed gate fees.

Alternatively, private players will be responsible for the collection of the source separated organics. The communities involved in source separation could benefit from the source separation associated incentives likely through MSWM fees reduction. Other benefits are largely the accompanying reduced environmental and human health risks from the $\mathrm{AD}$ and composting of biodegradable MSW compared to its open and indiscriminate dumping. Communities will also benefit from biogas which they could purchase and alternatively use for cooking. There is also envisaged increased availability of renewable electricity from the $\mathrm{AD}$ biogas associated CHP generation. The biogas potential production is as shown in Table 3. 
Table 1: Goals, strategies and key actions in the Zimbabwe NISWMP promoting MSWM decentralisation

\begin{tabular}{|c|c|c|c|}
\hline Goal & Strategies & \multicolumn{2}{|c|}{ Key Actions } \\
\hline Minimize SW generation. & $\begin{array}{l}\text { Encourage the public to prevent } \\
\text { SW generation. }\end{array}$ & i. & Promote reduction of waste generation at household level. \\
\hline $\begin{array}{l}\text { Ensure source separation of solid } \\
\text { waste. }\end{array}$ & $\begin{array}{l}\text { Put in place appropriate source } \\
\text { separation of SW systems at } \\
\text { sources. }\end{array}$ & ii. & $\begin{array}{l}\text { Separate waste into biodegradable and non-biodegradable } \\
\text { fractions. } \\
\text { Introduce incentives for source separation to bring in public } \\
\text { and industry buy in. }\end{array}$ \\
\hline $\begin{array}{l}\text { Promote the reuse of biodegradable } \\
\text { SW to reduce its quantities } \\
\text { earmarked for disposal sites. }\end{array}$ & $\begin{array}{l}\text { Use biodegradable SW for } \\
\text { gardening and livestock feed. }\end{array}$ & $\begin{array}{l}\text { ii. } \\
\text { iii. }\end{array}$ & $\begin{array}{l}\text { Use of biodegradable SW for gardening and livestock feed at } \\
\text { household level. } \\
\text { Establish viable markets for biodegradable SW. } \\
\text { Packaged manure production from biodegradable SW } \\
\text { composting or vermi-composting. }\end{array}$ \\
\hline \multirow{4}{*}{$\begin{array}{l}\text { Maximize materials and resource } \\
\text { recovery. }\end{array}$} & $\begin{array}{l}\text { Support the development of a } \\
\text { recycling economy. }\end{array}$ & $\begin{array}{l}\text { iii. } \\
\text { iv. } \\
\text { v. } \\
\text { vi. }\end{array}$ & $\begin{array}{l}\text { Allocate land to enable informal waste traders/community } \\
\text { groups to separate and sort recyclable SW. } \\
\text { Establish industrial sites or recycling centers where a } \\
\text { multitude of recycling firms can rent space. } \\
\text { Establish waste recycling projects at institutions such as } \\
\text { schools, tertiary education institutions and hotels. } \\
\text { Encourage the private sector, small and medium enterprises } \\
\text { to develop and upgrade SW management facilities. } \\
\text { Establish a supportive institutional framework for private } \\
\text { recycling enterprises. } \\
\text { Establish research informed markets for recycled materials } \\
\text { and resources. }\end{array}$ \\
\hline & $\begin{array}{l}\text { Promote SW value addition and } \\
\text { innovation on recycled materials } \\
\text { and resources. }\end{array}$ & ii. & $\begin{array}{l}\text { Invest in the development of technologies for SW value } \\
\text { addition and innovation on recycled materials and resources. } \\
\text { Use of indigenous knowledge systems on SW value addition } \\
\text { like basket weaving, local crafts etc. }\end{array}$ \\
\hline & $\begin{array}{l}\text { Establish an enabling policy and } \\
\text { legal framework for multi } \\
\text { stakeholder participation in SW } \\
\text { recycling. }\end{array}$ & $\begin{array}{l}\text { i. } \\
\text { ii. } \\
\text { iii. }\end{array}$ & $\begin{array}{l}\text { Institute legislative, regulatory and institutional review to } \\
\text { support recycling markets and promote SW recycling. } \\
\text { Introduce licensing system for SW recycling, incentives and } \\
\text { subsidies for investment in SW recycling promotion. } \\
\text { Establish a Green Fund where individuals, banks and private } \\
\text { sector contribute to support SW recycling. }\end{array}$ \\
\hline & $\begin{array}{l}\text { Explore and promote energy } \\
\text { recovery from SW. }\end{array}$ & & $\begin{array}{l}\text { Construction of AD facilities at established recycling centers } \\
\text { and institutions like schools, universities, prisons as well as } \\
\text { markets and hotels. } \\
\text { Establish combined Heat and Power generation facilities } \\
\text { from AD derived biogas. }\end{array}$ \\
\hline \multirow{3}{*}{$\begin{array}{l}\text { Restructure and introduce an } \\
\text { efficient source separated waste } \\
\text { collection system. }\end{array}$} & $\begin{array}{l}\text { Establish strong diversified and } \\
\text { appropriate SW collection systems } \\
\text { for source separated biodegradable } \\
\text { (wet waste) and non-biodegradable } \\
\text { waste (dry waste) fractions. }\end{array}$ & & $\begin{array}{l}\text { Introduce a collection system for recyclables where collection } \\
\text { points include schools, office blocks and apartments. } \\
\text { Establish a kerbside collection system with citizens' drop off } \\
\text { or citizens' convenient centers where households or } \\
\text { institutions bring the recyclables. } \\
\text { Establish partnerships amongst stakeholders namely } \\
\text { residents, ULAs, CBOs, individual waste collectors and } \\
\text { private sector to optimize collection of sorted SW. } \\
\text { Integrate the residents, ULAs, private sector, informal } \\
\text { collectors and CBOs into the IMSWM system within their } \\
\text { local authorities. }\end{array}$ \\
\hline & $\begin{array}{l}\text { Pilot various SW management and } \\
\text { collection systems in different } \\
\text { residential areas. }\end{array}$ & i. & $\begin{array}{l}\text { Pilot ISWM systems in high density areas where individuals } \\
\text { and CBOs collect, sort and recover, value add, compost and } \\
\text { sell the products. } \\
\text { Pilot ISWM systems in high density areas characterised by a } \\
\text { kerbside collection system with citizens' drop off or citizens } \\
\text { convenient centers where citizens bring in their source } \\
\text { separated waste and subjected to a subsidy to reduce their } \\
\text { individual household SW collection fee. }\end{array}$ \\
\hline & $\begin{array}{l}\text { Enhance ULAs capacity to provide } \\
\text { efficient SW } \\
\text { management services. }\end{array}$ & & $\begin{array}{l}\text { Review ULAs by laws to equip residents to provide } \\
\text { appropriate SW receptacles at their households and have SW } \\
\text { collection fees reduction incentive. }\end{array}$ \\
\hline
\end{tabular}


Invest in and build environmentally sustainable SW management infrastructure and systems.

Construct, upgrade and or
rehabilitate SW collection,
management, treatment and
disposal infrastructure

disposal infrastructure. i. Construct, upgrade and or rehabilitate SW incineration, composting, treatment/neutralization and energy recovery facilities.

Table 2: Annual MSW and specific MSW fraction generation figures for Harare City and its surrounding ULAs [35]

\begin{tabular}{|c|c|c|c|c|c|c|}
\hline \multirow[b]{2}{*}{ ULA } & \multirow{2}{*}{\begin{tabular}{|c|} 
Estimated \\
annual \\
MSW \\
generation \\
(ton)
\end{tabular}} & \multicolumn{5}{|c|}{ Amount of MSW Fractions (ton) } \\
\hline & & Organic & Plastic & Metals & Paper & Glass \\
\hline Harare & 325,266 & 136,612 & 107,338 & 26,021 & 45,537 & 9,758 \\
\hline Chitungwiza & 78,148 & 32,822 & 25,789 & 6,252 & 10,941 & 2,344 \\
\hline Norton & 14,802 & 6,217 & 4,885 & 1,184 & 2,072 & 444 \\
\hline Ruwa & 12,412 & 5,213 & 4,096 & 993 & 1,738 & 372 \\
\hline Epworth & 36,674 & 15,403 & 12,102 & 2,934 & 5,134 & 1,100 \\
\hline Total & 467,303 & 196,267 & 154,210 & 37,384 & 65,422 & 14,019 \\
\hline
\end{tabular}

Table 3: Estimated biogas potential for Harare City and its surrounding ULAs [44]

\begin{tabular}{|l|c|c|c|c|c|c|}
\hline ULA & Harare & $\begin{array}{c}\text { Chitungwi } \\
\text { za }\end{array}$ & Norton & Ruwa & $\begin{array}{c}\text { Epwort } \\
\text { h }\end{array}$ & Total \\
\hline Organic MSW generated (tons) & 136,612 & 32,822 & 6,217 & 5,213 & 15,403 & 196,267 \\
\hline Estimated annual biogas potential $\left(\mathbf{m}^{3}\right)$ & $1.59 \mathrm{E}+07$ & $3.82 \mathrm{E}+06$ & $\begin{array}{c}7.24 \mathrm{E}+0 \\
5\end{array}$ & $\begin{array}{c}6.07 \mathrm{E}+0 \\
5\end{array}$ & $\begin{array}{c}1.79 \mathrm{E}+0 \\
6\end{array}$ & $2.29 \mathrm{E}+07$ \\
\hline
\end{tabular}

\subsection{Recycling}

There is great emphasis on the need to increase the recycling levels in Zimbabwe. For example, in Harare only $9.6 \%$ of the MSW generated in Harare is recycled translating to only 23,000 tons of the over 467,000 tons generated. At least $20 \%$ of the nonbiodegradable MSW equivalent to at least 56,000 tons has to be recycled [35] thus double the current recycling level. To meet this target therefore, recycling could be done at household, institutional and community level. It will have to be enhanced by the source separation of MSW generated. Source separation of MSW promotes stakeholder and citizens participation in any waste management system thus enhancing decentralisation. Citizens drop off or convenient centers could also be established under a kerbside waste collection system where those in the recycling business will come and separate the materials, they want for their recycling business. Recycling provides economic and employment opportunities to communities who would be involved either in source separation through incentives or those collecting recyclable materials to recycling facilities. The model for operation under a decentralised model will be to have recycling companies either collecting the source separated recyclables or having ULAs depositing the recyclables at a mutually agreed gate fee with waste pickers depositing their recyclable materials at an agreed cost. Those involved in source separation will benefit from reduced waste management fees they pay to ULAs through incentives for their participation in source separation.

\subsection{Thermal Treatment}

The incineration of MSW generated in Harare is likely to be done at institutional, community or industrial scale. In addition to www.astesj.com the better environmental performance of incinerating MSW generated in Harare compared to its landfilling observed by [35], authors in [37] reported the suitability of MSW generated in Harare to be treated via incineration with a lower heating value of between $10100 \mathrm{~kJ} / \mathrm{kg}$ and $9320 \mathrm{~kJ} / \mathrm{kg}$ giving an estimated $3.8 \times 106 \mathrm{GJ}$ per annum. The lower heating value and incineration efficiency thus could be enhanced by the source separation of biodegradable MSW. The incineration of at most $80 \%$ of the non-biodegradable MSW generated translates to the incineration of at most 217,000 tons of non-biodegradable MSW estimated to give at most 1.96 $\times 106$ GJ per annum. Like under AD and composting, ULAs could collect the source separated non-biodegradable MSW meant for incineration and deposit at incineration facilities at an agreed gate fee whereas incinerator operators can as well do the collection with residents benefiting in various forms from their participation in the decentralised MSWM system. Table 4 thus gives the estimates of potential energy generation from the incineration of the nonbiodegradable MSW under each jurisdiction within and surrounding Harare.

\section{Discussion}

MSWM decentralisation promotes the backyard composting of organic MSW fraction at households and or the industrial scale AD and composting of source separated or mechanically separated organic MSW fraction. The industrial scale AD and composting of source separated organic MSW fraction leads to the production of a biofertilizer from the $\mathrm{AD}$ digestate and compost from composting thereby providing the safe utilisation or disposal of the digestate and compost as a nutrient rich biofertilizer devoid of biological, chemical and physical pollutants. Source separated 
organic MSW fraction provides the AD and composting feedstock quality necessary for the production of biofertilizer from high quality $\mathrm{AD}$ digestate and compost that will be used for agricultural application [38]. The AD and composting associated nuisance in the form of noise from heavy MSW collection vehicles and facility operations, odours, bio-aerosols, environmental and human health impacts has however raised concerns from residents despite the undisputed associated benefits [39-42]. Solutions to these concerns could incorporate the installation of smaller decentralised $\mathrm{AD}$ and composting facilities of low operational capacities distributed within the ULAs as proposed by [43] unlike the large centralised facilities. These distributed and decentralised smaller AD and composting facilities of low capacities results in the reduction of distances travelled by MSW collection vehicles subsequently yielding corresponding reductions in fuel consumed, transport costs, GHG and other emissions namely traffic and noise. The renewable electricity generated from the CHP generation through the combustion of $\mathrm{AD}$ derived biogas will serve the local communities to bring about increased residents' acceptance of the $\mathrm{AD}$ and composting facilities in their neighbourhoods.

Opportunities for the anaerobic co-digestion of source separated organic MSW fraction and dewatered sewage sludge in the smaller decentralised facilities of low capacities distributed across the ULAs in and around Harare also exist. This will entail composting of the co-digestion digestate regarded ideal for localized and small communities' setups. The co-digestion of organic MSW fraction and sewage sludge increases the AD biogas yield and improves AD process stability [45, 46]. Decentralisation potentially facilitates for the participation of residents in material recovery or recycling activities which is anticipated to increase materials recycling levels beyond the current $9.6 \%$ of MSW generated reported by [4]. Decentralisation promotes the development and construction of decentralised community level WTS, CDOPs or CCCs as well as BBCs. All the proposed decentralised MSWM systems can reduce the amount of MSW on a volumetric and weight basis to be sent to landfills subsequently reduce land demand for MSW landfilling purposes. Thermal waste treatment methods to recover energy through incineration, pyrolysis and gasification facilities can potentially be integrated into the proposed MSWM decentralisation models.

A life cycle assessment (LCA) study by [47] on future likely least impactful MSWM systems for ULAs in and around Harare showed that incorporating the $\mathrm{AD}$ of organic MSW fraction generated in ULAs in and around Harare for CHP generation with $20 \%$ recovery of materials from the inorganic MSW fraction and incineration of $80 \%$ of the remaining inorganic MSW fraction for CHP generation with flue gas treatment and incinerator bottom ash use as road construction material yields the least environmental impacts (acidification, eutrophication, global warming and human health) potentials. Authors in [37] observed that $75 \%$ on a weight basis of MSW generated in ULAs in and around Harare is suitable for treatment via incineration without the need for supplementary fuel due to its lower heating value of $10.1 \mathrm{MJ}$ per $\mathrm{kg}$ with a potential annual energy yield of $3.8 \times 106 \mathrm{GJ}$ (112 GWh per annum) which will increase the national annual electricity share from MSW and bio-fuels by over $0.9 \%$ to $2.2 \%$ from the prevailing minimum of $1.3 \%$. The incineration of the MSW generated in ULAs in and around Harare will potentially reduce the amount of MSW earmarked for landfilling by $40 \%$ [37]. Therefore, source www.astesj.com separation of organic MSW fraction and subjecting it to either composting or $\mathrm{AD}$ is likely to increase the efficiency during the inorganic MSW incineration since organic biodegradable MSW fractions have been widely reported to compromise the incineration performance. Just like small scale distributed AD and composting facilities for managing and treating the organic MSW fraction generated in ULAs in and around Harare, small scale distributed incineration facilities can be deployed to manage and treat the inorganic and combustible MSW fractions.

MSWM decentralisation has largely failed to take off in Zimbabwe due to residents' attitudes and behaviors towards MSWM and MSW disposal. Authors in [3] noted that initiatives towards CBMSWM implementations in Bulawayo, Zimbabwe's second biggest City, failed since it failed to change the attitudes and behaviors of Bulawayo residents on MWSM and MSW disposal. The authors [3] further noted absence of different MSWM initiatives undertaken by $\mathrm{CBO}$ s that embraced and incorporated materials recycling. This is however different with Harare where the Zimbabwe Sunshine group has a MSWM system developed based on CBMSWM and IMSWM model in selected suburbs and at the Zimbabwe Exhibition Park. Interestingly the Zimbabwe Sunshine Group has already constructed CDOPs or CCCs where recyclable MSW fractions are brought and sorted having also started the collection of MSW fractions for their reuse and recycling from households and institutions. The success story of the Zimbabwe Sunshine Group should be used to scale up such initiatives across all the ULAs in and around Harare and possibly nationally.

The coming into effect of the NISWMP in July 2014 was viewed as a welcome development as it provided for decentralisation hence MSWM decentralisation initiatives were envisaged to emerge from its provisions. The plan provides several key strategies and action points that support the decentralisation of MSWM within ULAs in Zimbabwe. Key actions include education in waste reduction, source separation of MSW, reuse of biodegradable MSW for gardening and livestock feed at household level, establishment of viable markets for biodegradable SW, production of manure from biodegradable SW composting or vermi-composting, establishment of community and industrial recycling centers, development of recycling projects at institutions, construction of $\mathrm{AD}$ facilities at established recycling centers and institutions, establish combined Heat and Power (CHP) generation facilities for $\mathrm{AD}$ derived biogas, putting in place a MSW collection system with CDOPS or CCCS and BBCs where households or institutions bring in MSW etc. as provided in Table 1. Worryingly all of these key actions as provided in the plan have not taken off over six years since the plan came into effect hence the need for urgent review and subsequent operationalization and implementation of the review findings.

The need for stakeholder inclusion and participation in all these key actions provided in the NISWMP is evidently clear. This is affirmed under goal 8 which seeks to promote cleanliness in Zimbabwe by involving the public, industry and government in efforts towards reducing, reusing and recycling all solid waste materials to manage and mitigate the SW associated public health and environmental impacts. Goal 7 further supports decentralisation as it provides for the need to educate and raise awareness amongst Zimbabwean citizens to better understand the 
T. Nhubu et al. / Advances in Science, Technology and Engineering Systems Journal Vol. 6, No. 2, 1029-1037 (2021)

Table 4: Estimated Energy potential from the incineration of the non-biodegradable MSW Harare City and its surrounding ULAs

\begin{tabular}{|l|c|c|c|c|r|r|}
\hline \multicolumn{1}{|c|}{ ULA } & Harare & Chitungwiza & Norton & \multicolumn{1}{c|}{ Ruwa } & Epworth & Total \\
\hline $\begin{array}{l}\text { Non-biodegradable MSW generated } \\
\text { (tons) }\end{array}$ & $188,654.28$ & $45,325.84$ & $8,585.16$ & $7,198.96$ & $21,270.92$ & $271,035.16$ \\
\hline $\begin{array}{l}\text { Estimated annual biogas potential (GJ } \\
\text { per annum) }\end{array}$ & $1.36 \mathrm{E}+06$ & $3.28 \mathrm{E}+05$ & $6.21 \mathrm{E}+04$ & $5.21 \mathrm{E}+04$ & $1.54 \mathrm{E}+05$ & $1.96 \mathrm{E}+06$ \\
\hline
\end{tabular}

importance of participating in source separation, materials and resources recovery and integrated and sustainable solid waste management. There is need for the reform of the available national legislation and ULAs' bylaws to ease the flexibility for entry and inclusion of other players in MSWM as ULAs are somehow reluctant to devolve and delegate some of the MSWM functions and roles despite their glaring failures to manage the MSW. Interestingly the tenth goal of the plan seeks to review and assess current legislation and institutional arrangements to improve implementation of ISWM amongst its key actions. Under strategy $\mathrm{C}$ of the plan is the need to decentralize MSWM authority to the lowest appropriate level as well as strengthening the capacities of ULAs to meet their obligations with regards to decentralizing MSWM authorities.

The Presidency, the highest office in Zimbabwe, made a proclamation that declared the first Friday of each calendar month being a national cleanup day for communities and citizens to take part in cleaning their surroundings. This is a significant milestone towards changing the citizens mindsets, attitudes and behaviors on MSWM, MSW disposal and general environmental stewardship. The Presidential proclamation is a significant and welcome development; however, it has to be complimented with the construction of safe MSW disposal facilities for the MSW that would have been collected during the national clean up since it is currently being dumped at dumpsites which are already classified as human health and environmental hazards thus the national clean up become another unsustainable problem transfer from communities to dumpsites. There is need for urgent development and construction of recycling, $\mathrm{AD}$ and composting, incineration and landfill facilities with only the inert materials and those from which materials and energy could not be further derived from sent to landfills. Zimbabwean citizens have not yet fully embraced the national cleanup day hence the need for extensive awareness raising together with other initiatives that will attract citizens to participate with the participation not only limited to sweeping and cleaning but allowing those who could provide the needed resources and equipment given the opportunity to do so. Above all the high literacy level in Zimbabwe is believed will enhance citizens participation easing the introduction and implementation of decentralised waste management systems.

\section{Conclusion and Recommendations}

The study has attempted to show that numerous MSWM decentralisation opportunities in ULAs in and around Harare exist anchored on the quantities of MSW generated and its characteristics, suitability for biological and thermal treatment methods as well as the available recycling potential. This is despite the prevailing MSWM challenges which have become potential human health and environmental hazards. The NISWMP thus has noted MSWM decentralisation potential and provides for the decentralisation of MSWM systems and functions. Another highlevel commitment for decentralisation is noted from the Presidential proclamation that declared the first Friday of every calendar month a national cleanup day which provide for every stakeholder's participation in MSWM in their local communities. However, reluctance to devolve MSWM functions by ULAs has been noted hence the need for legislative and institutional reforms as provided for under goal 10 of the plan. All the key actions regarding MSWM decentralisation in the plan have not been implemented with no waste management policy in sight as provided six years after the plan came into effect thus the need for urgent review and subsequent operationalization and implementation of the review findings. The lack of review on the available legislations and institutions has hindered MSWM decentralisation. Despite the available opportunities for MSWM decentralisation in Harare, there is need for environmental sustainability, economic feasibility, social acceptability and material and energy recovery potential assessment studies of the likely decentralised IMSWM and CBMSWM models. Further studies that quantify the associated environmental impacts, materials and energy recovery potentials as well as the economic feasibility of local level decentralised MSWM need to be undertaken.

\section{Conflict of Interest}

The authors declare no conflict of interest.

\section{Acknowledgment}

Special thanks go to University of Johannesburg postdoctoral fellowship that supported this study. The authors would like to thank the Life Cycle Initiative for the 2017 Life Cycle award with SimaPro software used for LCIA.

\section{References}

[1] A. M. Simon, Analysis of Activities of Community Cased Organizations Involved in Solid Waste Management, Investigating Modernized Mixtures Approach: The Case of Kinondoni Municipality, Dar es Salaam, Tanzania., Masters Thesis, Wageningen University, 2008.

[2] EMA, Hazardous Waste Management Regulations; Statutory Instrument (SI) 10 of 2007,2007

[3] N. I. Sinthumule and S. H. Mkumbuzi, "Participation in community-based solid waste management in Nkulumane suburb, Bulawayo, Zimbabwe," Resources, 8(1), 30-46, 2019, doi.org/10.3390/resources8010030.

[4] EMA, Waste generation and management in Harare, Zimbabwe: Residential areas, commercial areas and schools, 2016.

[5] J. Okot-Okumu and R. Nyenje, "Municipal solid waste management under decentralisation in Uganda," Habitat International, 35(4), 537-543, 2011, doi.org/10.1016/j.habitatint.2011.03.003.

[6] C. Zurbrügg, S. Drescher, A. Patel, and H. C. Sharatchandra, "Decentralised composting of urban waste - an overview of community and private 
initiatives in Indian cities," Waste management, 24(7), 655-662, 2004, doi.org/10.1016/j.wasman.2004.01.003.

[7] A. Massarutto, A. de Carli, and M. Graffi, "Material and energy recovery in integrated waste management systems: A life-cycle costing approach," Waste management, 31(9-10), 2102-2111, 2011, doi.org/10.1016/j.wasman.2011.05.017.

[8] F. H. Mudzengerere and A. Chigwenya, "Waste Management in Bulawayo city council in Zimbabwe: In search of Sustainable waste Management in the city," Journal of Sustainable Development in Africa, 14(1), 228-244, 2012.

[9] N. K. A. Malik, S. H. Abdullah, and L. A. Manaf, "Community participation on solid waste segregation through recycling programmes in Putrajaya," Procedia Environmental Sciences, 30, 10-14,2015, doi.org/10.1016/j.proenv.2015.10.002.

[10] J. K. Seadon, "Integrated waste management-Looking beyond the solid waste horizon," Waste management, 26(12), 1327-1336, 2006, doi.org/10.1016/j.wasman.2006.04.009.

[11] L. A. Guerrero, G. Maas, and W. Hogland, "Solid waste management challenges for cities in developing countries," Waste management, 33(1), 220-232, 2013, doi.org/10.1016/j.wasman.2012.09.008.

[12] S. A. Ahmed and S. M. Ali, "People as partners: Facilitating people's participation in public-private partnerships for solid waste management," Habitat International, 30(4), 781-796, 2006, doi.org/10.1016/j.habitatint.2005.09.004.

[13] M. Sharholy, K. Ahmad, R. C. Vaishya, and R. D. Gupta, "Municipal solid waste characteristics and management in Allahabad, India," Waste management, 27(4), 490-496, 2007, doi.org/10.1016/j.wasman.2006.03.001.

[14] A. A. Babaei, N. Alavi, G. Goudarzi, P. Teymouri, K. Ahmadi, and M. Rafiee, "Household recycling knowledge, attitudes and practices towards solid waste management," Resources, Conservation and Recycling, 102, 94100, 2015, /doi.org/10.1016/j.resconrec.2015.06.014.

[15] T. Nhubu, E. Muzenda, C. Mbohwa, and B. Patel, "Impacts of waste management practices on water resources in Harare," in WASTES 2019, Lisbon, Portugal, 1-6, 2019.

[16] A. Mubaiwa, Community Based Waste Management in Urban Areas, 2019

[17] D. C. Wilson, "Development drivers for waste management," Waste Management \& Research, 25(3), 198-207, 2007, doi.org/10.1177/0734242X07079149.

[18] G. P. J. Dijkema, M. A. Reuter, and E. V. Verhoef, "A new paradigm for waste management," Waste management, 20(8), 633-638, 2000, doi.org/10.1016/S0956-053X(00)00052-0.

[19] J. T. Tukahirwa, A. P. Mol, and P. Oosterveer, "Civil society participation in urban sanitation and solid waste management in Uganda," Local envrironment, 15(1), 1-14, 2010, doi.org/10.1080/13549830903406032.

[20] EMA, Zimbabwe's integrated solid waste management plan, 2014

[21] T. Nhubu, E. Muzenda, M. Belaid, and C. Mbohwa, "Implementation status assessment of the Zimbabwe national integrated solid waste management plan," in ICEESEN2020, 1-6, 2020.

[22] T. Sekito, T. B. Prayogo, Y. Dote, T. Yoshitake, and I. Bagus, "Influence of a community-based waste management system on people's behavior and waste reduction," Resources, Conservation and Recycling, 72, 84-90, 2013, doi.org/10.1016/j.resconrec.2013.01.001.

[23] L. Xiao, G. Zhang, Y. Zhu, and T. Lin, "Promoting public participation in household waste management: A survey based method and case study in Xiamen city, China," Journal of Cleaner Production, 144, 313-322, 2017, doi.org/10.1016/j.jclepro.2017.01.022.

[24] Y. A. Rigasa, A. G. Badamasi, N. Galadimawa, and G. U. Abubakar, "Community based solid waste management strategy: A case study of Kaduna metropolis," WIT Transactions on Ecology and the Environment, 210, 761-772, 2017, doi.org/ 10.2495/SDP160641.

[25] M. Colon and B. Fawcett, "Community-based household waste management: Lessons learnt from EXNORA's zero waste management scheme in two South Indian cities," Habitat International, 30(4), 916-931, 2006, doi.org/10.1016/j.habitatint.2005.04.006.

[26] J. Mongkolnchaiarunya, "Promoting a community-based solid-waste management initiative in local government: Yala municipality, Thailand," Habitat International, 29(1), 27-40, 2005, doi.org/10.1016/S01973975(03)00060-2.
[27] W. Nchito and G. A. Myers, "Four caveats for participatory solid waste management in Lusaka, Zambia," Urban Forum, 15, 109-133, 2004.

[28] D. Chikobvu and F. Makarati, "The challenges of solid waste disposal in rapidly urbanizing cities: A case of highfield suburb in Harare, Zimbabwe," Journal of Sustainable Development in Africa, 13(7), 184-199, 2011.

[29] F. McDougall, P. R. White, M. Franke, and P. Hindle, Integrated Solid Waste Management: A Lifecycle Inventory, Blackwell Science, 2001.

[30] B. Thomas and F. McDougall, "International expert group on life cycle assessment for integrated waste management," Journal of Cleaner Production, 13(3), 321-326, 2005, doi.org/10.1016/j.jclepro.2004.02.021.

[31] N. Kollikkathara, H. Feng, and E. Stern, "A purview of waste management evolution: special emphasis on USA," Waste management, 29(2), 974-985, 2009, doi.org/10.1016/j.wasman.2008.06.032.

[32] A. van de Klundert and J. Anschutz, Integrated sustainable waste management - the concept: tools for decision-makers. Experiences from the Urban Waste Expertise Programme (1995-2001), 2001.

[33] R. K. Henry, Z. Yongsheng, and D. Jun, "Municipal solid waste management challenges in developing countries - Kenyan case study," Waste management, 26(1), 92-100, 2006, doi.org/10.1016/j.wasman.2005.03.007.

[34] A. J. Morrissey and J. Browne, "Waste management models and their application to sustainable waste management," Waste management, 24(3),297-308, 2004, doi.org/10.1016/j.wasman.2003.09.005.

[35] T. Nhubu and E. Muzenda, "Determination of the Least Impactful Municipal Solid Waste Management Option in Harare, Zimbabwe," Processes, 7(11), 785, 2019, doi.org/10.3390/pr7110785.

[36] T. Nhubu, E. Muzenda, C. Mbohwa, and E. Agbenyeku, "Comparative assessment of compositing and anaerobic digestion of municipal biodegradable waste in Harare, Zimbabwe," Environmental Progress \& Sustainable Energy, 39(4), e13376, 2020, doi.org/10.1002/ep.13376.

[37] T. Nhubu, E. Muzenda, M. Belaid, and C. Mbohwa, Biogas potential from biomethanisation of biodegradable municipal solid waste generated in Harare, in Handbook of solid waste management, C. Baskar, S. Ramakrishna, S. Baskar, R. Sharma, and A. Chinnappan, Eds.: Springer, In Press.

[38] L. Makarichi, R. Kan, W. Jutidamrongphan, and K. A. Techato, "Suitability of municipal solid waste in African cities for thermochemical waste-toenergy conversion: The case of Harare Metropolitan City, Zimbabwe.," Waste Management \& Research, 37(1), 83-94, 2019, doi.org/10.1177/0734242X18804029.

[39] T. Al Seadi, B. Drosg, W. Fuchs, D. Rutz, and R. Janssen, Biogas digestate quality and utilization, in The biogas handbook: Woodhead Publishing, 2013.

[40] S. Sironi, L. Capelli, P. Céntola, R. Del Rosso, and M. Il Grande, "Continuous monitoring of odours from a composting plant using electronic noses," Waste management, 27(3), 389-397, 2007 , doi.org/10.1016/j.wasman.2006.01.029 .

[41] J. L. Domingo and M. Nadal, "Domestic waste composting facilities: a review of human health risks," Environment International, 35(2), 382-389, 2009, doi.org/10.1016/j.envint.2008.07.004.

[42] L. Giusti, "A review of waste management practices and their impact on human health," Waste management, 29(8), 2227-2239, 2009, doi.org/10.1016/j.wasman.2009.03.028.

[43] EU Commission, Green Paper on the management of bio-waste in the European Union, 2008,

[44] CalRecyle. Current Anaerobic Digestion Technologies Used for Treatment of Municipal Organic Solid Waste, 2008.

[45] R. Dereli, K, M. Ersahin, E, C. Gomec, Y, I. Ozturk, and O. Ozdemir, "Codigestion of the organic fraction of municipal solid waste with primary sludge at a municipal wastewater treatment plant in Turkey," Waste management, 28(5), 404-410, 2010, doi.org/10.1177/0734242X09338227.

[46] J. C. Kabouris, U. Tezel, S. G. Pavlostathis, M. Engelmann, A. C. Todd, and R. A. Gillette, "The anaerobic biodegradability of municipal sludge and fat, oil, and grease at mesophilic conditions," Water Environment Research, 80(3), 212-221, 2008, doi.org/10.2175/106143007X220699.

[47] T. Nhubu, E. Muzenda, C. Mbohwa, and E. Agbenyeku, Comparative environmental LCA of thermal and anaerobic treatment options for municipal solid waste in Zimbabwe, 2018. 